\title{
Efficacy of laparoscopic ligation of the mesovarium of the mare in the standing position without removal of the ovary
}

\author{
Astrid B. M. Rijkenhuizen', Frederik H. Jonker ${ }^{2}$ and Guy C. M. Grinwis ${ }^{3}$ \\ 1 Equine Surgery Consultancy, Wijk bij Duurstede, the Netherlands \\ 2 Department of Population Health Sciences, Section Farm Animal Health, Faculty of Veterinary Medicine, Utrecht University, Utrecht, the Netherlands \\ ${ }^{3}$ Department of Biomolecular Health Sciences, Pathology Division, Faculty of Veterinary Medicine, Utrecht University, Utrecht, the Netherlands
}

\begin{abstract}
Summary: The prospective controlled study with the ligation of the spermatic cord in abdominal cryptorchid horses by laparoscopic approach results in a functional castration. To examine the effect of ligation of the mesovarium on the functional viability of the ovary in five mares (one Dutch Warmblood and 4 Welsh ponies), from 3 to 16 years of age, with normal ovaries, the mesovarium, including the ovarian artery and vein, was ligated intra-abdominally using a laparoscopic technique in the standing position. The ovaries were left in place. Post-operative estrogen and progesterone levels were measured. Bilateral relaparoscopy was performed on day 14, day 28 and 5 months after the initial surgery in all 5 mares and the mares were subsequently euthanized. Autopsy was performed and the ovaries and uterus were examined macroscopically and histologically. Additionally, the same laparoscopic procedure was performed on 4 patients with informed consent of the owners. In result the mean oestrogen and progesterone level of 7 out of 9 mares were low after surgery. The procedure of a two-step ligation of the ovary, without removing the ovary, was successful in 15 out of the 18 ovaries (83\%). In conclusion the castration of mares by ligation, without removal of the ovaries, by laparoscopic intervention is possible. The surgical technique for devitalisation of the ovaries is safe and represents a method of castrating in the standing patient in a minimal invasive way. However, the procedure resulted in effective castration only in 6 of the 9 mares (67\%). The failure was probably technique-based and further modification of the applied procedure is necessary to improve the success rate. The low number of mares limitates the significance of the study.
\end{abstract}

Keywords: mare, castration, ovariectomy, standing position, efficacy

Citation: Rijkenhuizen A. B. M., Jonker F. H., Grinwis G. C. M. (2021) Efficacy of laparoscopic ligation of the mesovarium of the mare in the standing position without removal of the ovary. Pferdeheilkunde 37, 9-17; DOI 10.21836/PEM20210102

Correspondence: Prof. Astrid Rijkenhuizen, Singel 10,3961CE Wijk bij Duurstede, The Netherlands; a.rijkenhuizen@gmail.com

Submitted: August 29, 2020 | Accepted: November 24, 2020

\section{Introduction}

Indications for removal of the ovaries are troublesome behaviour, prevention of oestrus in riding mares, or ovarian diseases like cyst, hematoma, abscess and tumour (Palmer 1993). Surgical approaches include colpotomy or vaginal approach, flank approach, ventral midline or paramedian approach and via laparoscopy in the standing or in recumbent position. Ovariectomy by conventional surgery seems to be associated with a higher frequency of perioperative complications than other elective surgery like castration (Nickels 1988). The introduction of laparoscopy under general anaesthesia and in the standing mare reduced the complication rate, but still the instrumental portal has to be enlarged to remove the resected ovary with increasing risk of wound infection (Röcken et al 2011). The ovarian stumps inside the abdomen are a risk of adhesion formation. To further reduce the complication rate, a technique similar to the laparoscopic castration of stallions (Rijkenhuizen and Grinwis 1999), was developed to castrate the mare by laparoscopic ligation of the mesovarium and the proper ligament without removal of the ovaries. It was hypothesized that in horses with ovaries without pathological changes, bilateral ligation of the mesovarium will result in functional castration.

\section{Materials and methods}

Five mares (one Dutch Warmblood and 4 Welsh ponies), from 3 to 16 years of age (median age 9.6 years), each with clinically normal ovaries, were included in the study. Prior to surgery food was withheld for $24 \mathrm{~h}$ and mares were given free access to water. Surgery was performed in spring. Mares were followed up through 5 months, after which they were euthanized for pathological and histological examination. All experimental procedures were approved by the Animal Experimental Committee of the Utrecht University (DEC98/152/cs).

The mares were restrained in stocks with the tail tied up and sedated with detomidine (Domosedan $\left.{ }^{\circledR}\right)^{1} 0.1 \mathrm{mg} / 100 \mathrm{~kg}$ BWT intravenously) together with buprenorphine $\left(\text { Temgesic }{ }^{\circledR}\right)^{2} 0.06 \mathrm{mg} / 100 \mathrm{~kg}$ BWT intravenously). Sedation was maintained with a continuous infusion of detomidine $15 \mathrm{mg}$ in $3 \mathrm{~L}$ Ringer solution; infusion rate guided by the clinical effect according to Van Dijk et al. 2002). The laparoscopic procedure was performed in both flanks of the horse, starting at the right side. Preparations for aseptic surgery were carried out using routine techniques. Local infiltration anaesthesia (subcutaneously, intramuscularly and subperitoneally) using lidocaine hydrochloride $2 \%$ with adrenalin ${ }^{3}$ was applied at the sites of the laparoscope and instrument portals. 
The portal for the laparoscope (diameter $10 \mathrm{~mm}$, length $57 \mathrm{~cm}$, straight forward viewing $0^{\circ}$ angle, Storz ${ }^{\circledR 4}$ ) was just dorsal to the internal oblique abdominal muscle, and $2 \mathrm{~cm}$ caudal to the last rib. After introduction of the laparoscope, the abdomen was distended using a carbon dioxide $\left(\mathrm{CO}_{2}\right)$-insufflator (Stor ${ }^{\circledR}$, flowrate 7-8 L/min) to a maximum intra-abdominal pressure of $6 \mathrm{~mm} \mathrm{Hg}$. The second trocar (Dr.Fritsch ${ }^{\circledR 5}$ guarded shield, $5.5 \mathrm{~mm}, 20 \mathrm{~cm}$ length), used for instrumentation, was inserted in the field of vision of the scope, approximately $4 \mathrm{~cm}$ caudal and $8-10 \mathrm{~cm}$ distal to the laparoscopic portal, directed slightly caudally. A third $5.5 \mathrm{~mm}$ trocar was placed in between the first two. These instrument portals were used for the introduction of the grasping forceps, scissor and ligature.

After routine abdominal exploration, the laparoscope was directed to the ovary. The mesovarium was anesthetized by the injection of $6 \mathrm{ml} 2 \%$ lidocaine with adrenalin through a $1.2-\mathrm{mm}$ injection cannula (size $5 \mathrm{~mm}$, length $43 \mathrm{~cm} \mathrm{Storz}{ }^{\circledR}$ ) and then perforated using an unipolar scissor $(5 \mathrm{~mm}$ with a connection for unipolar coagulation, Storz ${ }^{\circledR}$ ), just caudal to the ovary and dorsal of the proper ligament (Ligamentum ovarii propium). Through the created hole, a ligature (polyglactin USP 2) ${ }^{6}$ was inserted from lateral to medial. The ligature was picked up with the forceps on the craniomedial site of the mesovarium and retracted extracorporally. A modified Roeder's knot was tied extracorporally and the slipknot was advanced with a pushrod, while pulling the long tail of the ligature, and firmly tightened. The suture was cut adjacent to the knot. A second ligature was inserted through the perforation in the mesovarium, which was picked up ventral of the proper ligament, including the caudal part of the mesovarium, the oviduct and mesosalpinx. Again the modified Roeder's knot was made extracorporally and tightened. Because the A. ovarica is situated in the cranial part of the mesovarium, a third ligature was placed on the cranial site, leaving a tissue bridge of maximal $5 \mathrm{~mm}$ apart from the first suture on that side. The ovary remained in situ. The same procedure was performed on the left flank, using identical laparoscopic portals. The insertion portals were closed in one layer (poliglecaprone USP 2-0)?.

All mares underwent relaparoscopy on both sites on day 14 , day 28 and 5 months after surgery, using the same location for the laparoscope as in the initial surgery. The aspect of the ovary (size, colour) was assessed as well as the presence of adhesions.

The mares were stall-rested for one week after surgery and then kept at pasture. They were examined clinically (general examination) on a daily basis for the first week and weekly for 5 months. Post-operatively, NSAID's were administered orally for 3 days.

Blood samples for white blood cell count (WBC) and serum fibrinogen determination were collected immediately preoperatively, on day 1, 7, 14, 28 and 5 months after surgery. Blood samples for determination of oestrogen and progesterone levels, using a solid phase radioimmunoassay (RIA) method as described by Gutjahr et al. (2000), were collected immediately preoperatively, on day 1, 7, 14, 28 and 5 months after surgery. At the beginning of each laparoscopic procedure peri- toneal fluid was retrieved, by using a laparoscopic needle, for analysis (total nucleated cell count (TNCC) and total protein concentration (TP)) to determine the post-operative peritoneal fluid values following standing laparoscopy ( 14 days, 28 days and 5 months after surgery respectively).

Transrectal examination and ultrasonography of the ovaries was performed preoperative and on day 3, 7, 14, 28 after surgery and the day of the euthanasia. In pony number 5 this examination could only be performed at the day of surgery due to its uncooperative character.

The mares were euthanized 5 months after the initial surgery. Autopsy of the abdominal cavity was performed. The abdomen was examined for adhesions or any other complication associated with surgery. Both ovaries and the uterus were harvested and submitted for (histo)pathological evaluation. The ovaries were examined grossly and subsequently histologically for the presence of vital ovarian structures. For this parts of the ovaries or tissue at the site where the ovaries should be located were fixed in $4 \%$ neutral-buffered formaldehyde, trimmed, paraffin embedded and routinely processed to $4 \mu \mathrm{m}$ tissue sections that were stained with haematoxylin and eosin.

Additionally, the same laparoscopic procedure was performed on 4 patients (Dutch Warmblood, 8-15 years of age) in spring with informed consent of the owners. Two mares were used as a teasing mare (one of them was euthanized 10 months post-operative due to reasons unrelated to the ovary) and the other 2 were operated on due to uncooperative and aggressive behaviour without neoplastic ovaries. The mares were only clinically observed during 1 week with a follow-up after one year. Preoperatively, 1 month and 1 year after surgery, blood was sampled for determination of oestrogen and progesterone levels using the RIA method.

\section{Results}

\section{Experimental group}

The laparoscopic procedure was performed without complications in all mares. Visualisation of the ovary and mesovarium was good, although the laparoscope was closer to the ovary on the right side compared to the left side due to the anatomical conformation. The ovaries varied from 5 to $8 \mathrm{~cm}$ in length, showed normal activity and contained no abnormal structures. The mean duration of the surgery was 42 minutes (range: 36 to 52 minutes). Perforation of the mesovarium or tightening of the ligatures did not result in a painful reaction. The mares did not show signs of abdominal discomfort post-operative, and food intake was the same as prior to surgery. One mare (number 1) showed an increase in body temperature $\left(39.2^{\circ} \mathrm{C}\right)$ for one day, 7 days after the third laparoscopy. Wound healing was in all cases by first intention, also of the incisions of the relaparoscopies.

Post-operative manual rectal examination indicated a small increase in size of the ovaries (about 10\% of the initial size) until 2 weeks after surgery. Then the size gradually decreased until the ovary could not be palpated anymore ( $0 \%$ of its original size), except for the right ovary of pony 
number 4 which kept a size of approximately $3.6 \mathrm{~cm}$. An adhesion was only palpable in pony number 2 at 14 days post-operative. Later on this adhesion was not palpable anymore.

The ultrasonography showed an initial decrease at day 3 followed by an increase in size of the ovaries. After 28 days, the size gradually decreased until no ovary could be found at 5 months post-operative, except for the right ovary in mare number 4.

The blood WBC count was within normal limits (reference range $\left.[\mathrm{rr}] 4.7-10.0 \times 10^{9} / \mathrm{I}\right)$ throughout the study with a mean increase of 2.9 (range 2.3-5.9) $\times 10^{9} / \mathrm{L} \mathrm{WBC}$ count the day after surgery compared to the preoperative day. The fibrinogen levels in the blood increased with $0.2-1.1 \mathrm{~g} / \mathrm{L}$ post-operative, the highest value reached 5-7 days post-operative. Values for peritoneal TNCC and TP were all within normal limits (TNCC $<5 \times 10^{9}$ cells $/ \mathrm{L}, \mathrm{TP}<25 \mathrm{~g} / \mathrm{L}$ ).

The mean oestrogen and progesterone level of 4 out of 5 mares were low after the first surgery, indicating absence of ovarian activity (Table 1). In mare number 4 , the oestrogen level decreased initially (day 2-5) but then increased (6.4 pg/ $\mathrm{ml}$ ) compared with the values of the preoperative day (4.53 $\mathrm{pg} / \mathrm{ml})$. Progesterone level decreased in all animals and was not in measurable range after day 2 postoperative. However, in mare number 4 the level of progesterone increased to 0.24 $\mathrm{ng} / \mathrm{ml}$ at day 28 post-operatively. In mare number 5 at day 15 after surgery the oestrogen level was only just above the lower level of detection, but could not be determined at day 28 after surgery. Unfortunately the blood samples of 5 months post-operative were lost.

Oestrus behaviour was not observed in the pasture. However, no active oestrus detection was performed.

\section{Relaparoscopy findings}

14 days after surgery, six of the 10 ovaries had a congested aspect. The vessels on the serosal surface of the ovaries were markedly dilated masking the underlying ovarian tissue (Fig. 1a). At the dorsal aspect, a cap of fibrovascular tissue could be recognised growing over the ovary. The other four ovaries had the aspect of a yellow smooth inert structure with a similar cap of granulation tissue growing over the ovary but without the presence of the congested serosal blood vessels (Fig. 2a). No remnant of the ligatures was detected.
At 28 days after surgery, all ovaries except one, which still had a congested aspect (Fig. 1b) although less than 14 days after surgery, had a yellow smooth serosal surface (Fig. 2b). The overgrowing cap of granulation tissue had increased in size and covered $1 / 2$ to $2 / 3$ of the ovary.

At 5 months post-operative, in 8 of the 10 ovaries the ovary could hardly or not be recognised and was embedded in the mesovarium (Fig. 1c and 2c). The visible part of these 8 ovaries had a diameter of approximately $1 \mathrm{~cm}$, a yellowish white colour and felt like a compact structure at palpation. In mare number 4 , the right ovary had the aspect of a normal active ovary (size 3 to $4 \mathrm{~cm}$ ) with a corpus luteum. The right ovary of mare number 5 had a diameter of approximately $1 \mathrm{~cm}$ and a yellow colour with blood vessels on its surface.

At re-laparoscopy, adhesions could be found from 14 days on in 2 mares. In one animal, the adhesions were located between the right ovary and the cecum, just below the duodenum over an area of $1 \mathrm{~cm}$. The caudal part of left ovary of this mare was attached to the mesentery of the colon descendens. At 28 days in this mare, a fibrous strand of $3 \mathrm{~cm}$ long and approximately $1 \mathrm{~cm}$ in diameter attached the right ovary to the cecum over an area of 0.5 to $2 \mathrm{~cm}$. In the same region, a chronic reactive lesion was seen on the duodenum with a length of $7 \mathrm{~cm}$ and $1 \mathrm{~cm}$ wide. The adhesion of the left ovary was similar to what was seen on day 14. At 5 months, the adhesion between the cecum and ovary was reduced in size $(0.5 \mathrm{~cm})$ but still $3 \mathrm{~cm}$ long. The fibrous strand was not under tension and did not interfere with the peristaltic of the duodenum or cecum. The adhesion on the left side had consolidated and the caudal part of the ovary was still attached to the mesentery.

In the second mare, only the left ovary showed adhesions with the mesentery at its medial and craniomedial aspect in an area of 1.5 by $1.5 \mathrm{~cm}$ and at its ventrocaudal part in an area of 2 by $2 \mathrm{~cm}$. At 28 days after the initial surgery, the extension of the adhesion had decreased and only the medial part was attached to the mesentery. At 5 months, the adhesion presented itself as a $6 \mathrm{~cm}$ long, $4 \mathrm{~cm}$ thick strand running from the cranial aspect of the uterus to the mesentery. The ovary was embedded in this strand.

The pony number 4 with the active ovary showed no adhesions, the inactive left ovary could not be detected by laparoscopy.

All abdominal fluid samples at day 0 had TP and TNCC within normal limits with a mean (range) of TP of $4.0(3.7-4.5) \mathrm{g} / \mathrm{L}(\mathrm{rr}<12 \mathrm{~g} / \mathrm{l})$

\begin{tabular}{|c|c|c|c|c|c|c|c|c|c|c|}
\hline \multirow{2}{*}{ Table 1} & \multicolumn{5}{|c|}{ Oestrogen pg/ml } & \multicolumn{5}{|c|}{ Progesteron ng/ml } \\
\hline & 1 & 2 & 3 & 4 & 5 & 1 & 2 & 3 & 4 & 5 \\
\hline DO & 7.4 & 4.53 & 3.72 & 4.53 & 4.69 & 13.97 & 22.76 & 1.22 & 8.39 & 17.34 \\
\hline D1 & 3.26 & 3.59 & 3.71 & $<3$ & $<3$ & 1.72 & 10.17 & 3.71 & 1.72 & 1.42 \\
\hline D7 & $<3$ & $<3$ & $<3$ & 3.27 & $<3$ & 0.10 & $<0.1$ & 0.20 & 0.10 & 0.20 \\
\hline D14 & $<3$ & $<3$ & $<3$ & 8.33 & 3.28 & $<0.1$ & $<0.1$ & $<0.1$ & $<0.1$ & $<0.1$ \\
\hline D28 & $<3$ & $<3$ & $<3$ & 6.40 & $<3$ & $<0.1$ & $<0.1$ & $<0.1$ & 0.24 & $<0.1$ \\
\hline
\end{tabular}


and TNCC of $4.3(3.2-9.2) \times 10^{9} / \mathrm{L}\left(\mathrm{rr}<9.3 \times 10^{9} / \mathrm{L}\right)$. The samples at day 14 revealed in all mares an increase in TP and TNCC: 36.6 (25.8-39.9) g/L respectively 32.5 (range $25.6-42.3) \times 10 \%$, indicating a reactive peritonitis. At day 28 in 4 mares TP and TNCC were within normal limits except for pony number $3(27.8 \mathrm{~g} / \mathrm{L})$ and $14.2 \times 10^{9} /$. At 5 months all values were within normal limits.

\section{Pathological findings}

At autopsy, 8 of the 10 ovaries had a yellowish brown-white colour, an average diameter of $1.5 \mathrm{~cm}$, and could hardly be recognised as an ovary. The cut surface showed a solid brown reddish aspect and contained cystic structures in one case. Histological examination revealed cell-poor fibrosis with aggregates of macrophages with hemosiderin pigment (Fig. 3) at the site of the ovaries with occasionally necrotic remnants of the corpora lutea. No follicles or corpora lutea were seen indicating the absence of ovarian activity, also the typical cell-rich spindle cell component typical of equine ovaries was absent.

The remaining two ovaries, both from the right side of two different mares, did contain vital ovarian tissue component. One of the ovaries was hardly recognisable as an ovary at the laparoscopic view, but showed at autopsy a cyst of 2.5 to $2.5 \mathrm{~cm}$ filled with a clear dark yellow fluid and on the cut surface a
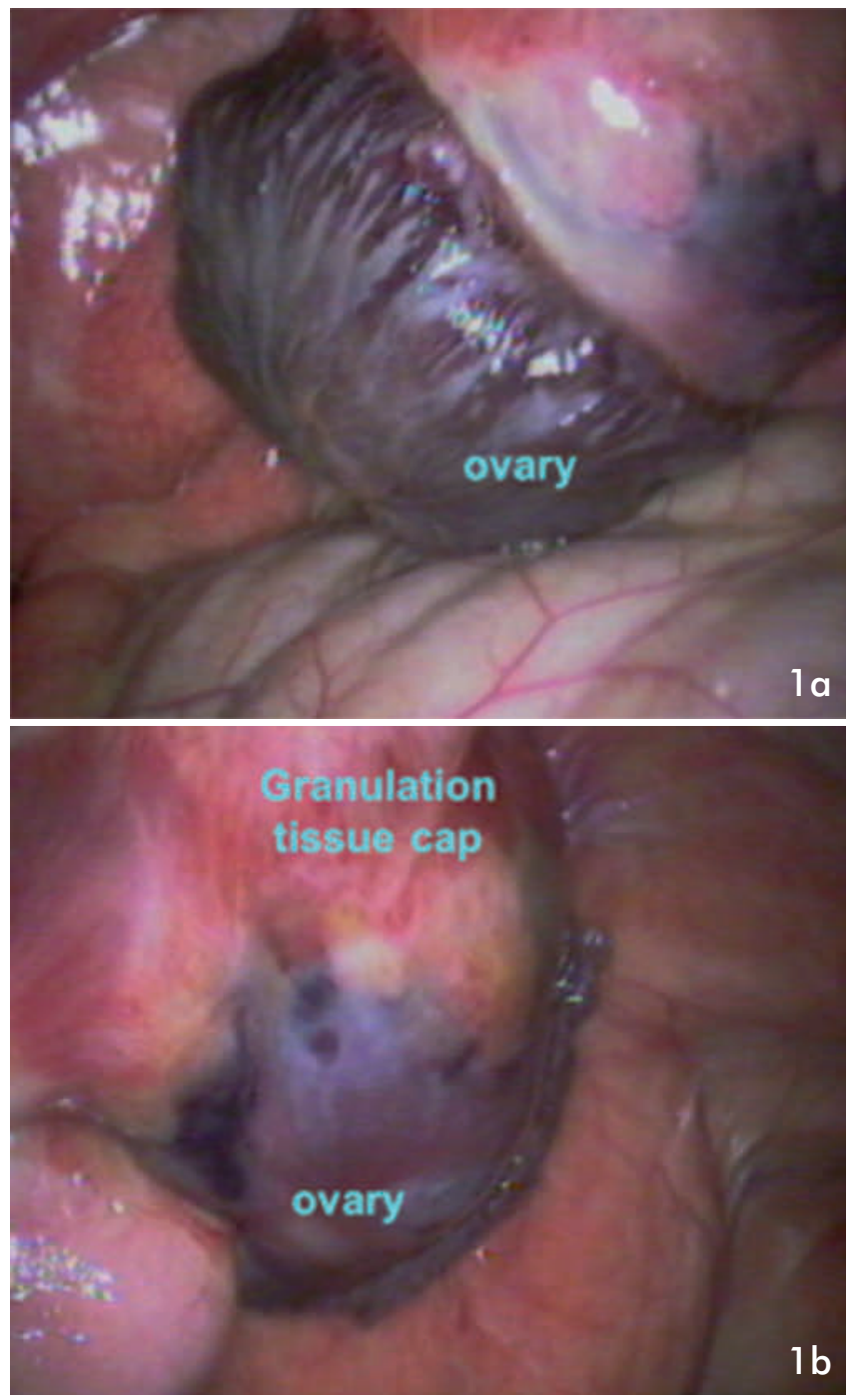

haemorrhagic area of $1 \mathrm{~cm}$ diameter. At histology 2 cysts were found separated by necrotic tissue containing vessels occluded by fibrin thrombi. One of the cysts was characterized by luteinisation of the wall. No oocytes, or follicular structures were noticed although vital stromal tissue was found similar to normal stroma of an equine ovary as well as large areas containing luteal cells (Fig. 4). The other ovary was laparoscopically recognised as an active ovary which was confirmed by macroscopy. Histology of this ovary showed large areas of vital stromal cells with scattered several primordial follicles (Fig. 5) as well as areas with luteal cells.

In all cases the uterus was well contracted with no macroscopical abnormalities. In the 3 mares with the inactive ovaries, the luminal epithelium was cuboidal to low columnar, the glands were straight and had a small diameter (Fig. 6), occasionally filled with fluid. In the two other mares, the uterus revealed hyperplastic glands that are regularly filled with secretum and lined by columnar epithelium with vacuolised plasma (suggestive of progesterone influence) and an oedematous aspect of the lamina propria (Fig. 7).

\section{Patient group}

In the 4 patients, the surgical procedure was also without complications. Follow-up information one year later revealed

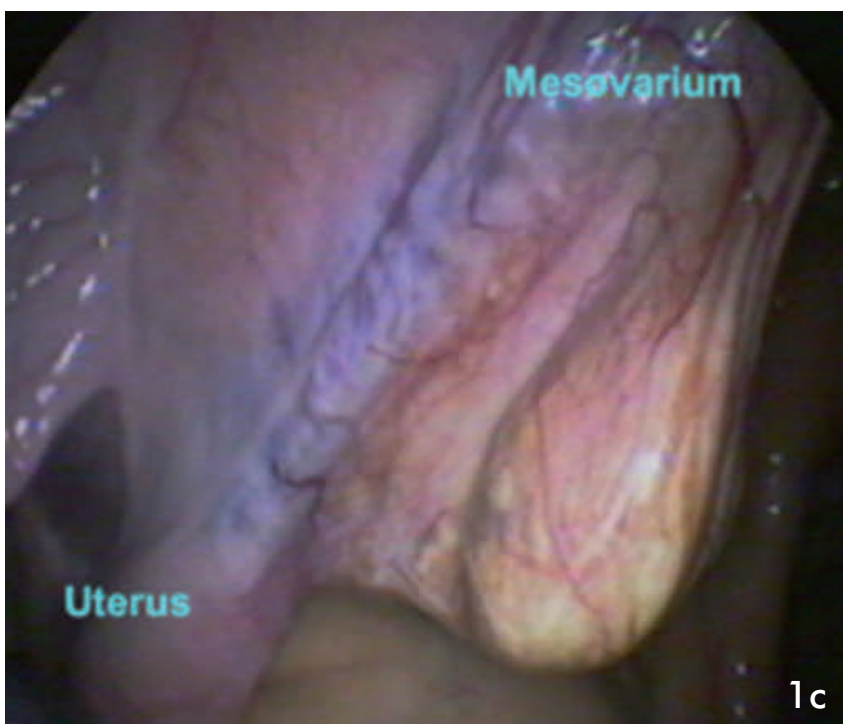

Fig. 1 Laparoscopic view of a congested ovary 14 (1a), 28 (1b) days and 5 months (1c) respectively after the initial surgery. a. The ovary has a congested aspect. The vessels are dilated and the ovary looks like a conglomerate of vessels. At the dorsal aspect, a cap of new vessels embedded in fibrous tissue can be recognised growing over the ovary. b. The ovary still has a congested aspect, the granulation cap has increased in size. c. The ovary can hardly be recognised and is embedded in the mesovarium. | Laparoskopische Ansicht eines gestauten Eierstocks 14 (1a), 28 (1b) Tage bzw. 5 Monate (1c) nach der ersten Operation. a. Der Eierstock macht einen gestauten Eindruck. Die Gefäße sind enweitert und der Eierstock sieht wie ein Konglomerat von Gefäßen aus. Auf der dorsalen Seite ist eine Kappe mit neven, in faserigem Gewebe eingebetteten Gefäßen zu erkennen, die über den Eierstock wachsen. b. Der Eierstock ist immer noch gestaut, die Granulationskappe hat sich vergröBert. c. Der Eierstock ist kaum zu erkennen und ist in das Mesovarium eingebettet. 
that of the 8 ligated ovaries one ovary (left side) was still active. This was indicated by the results of the ultrasound examination and the fact that oestrogen and progesterone level were within normal limits. In the breeding season one month and one year after the surgery, the mean oestrogen $(<3 \mathrm{pg} /$ $\mathrm{ml}$ ) and progesterone $(<0.1 \mathrm{ng} / \mathrm{ml})$ level of the other 3 mares were low, indicating absence of ovarian activity. These mares had shown no oestrus signs after surgery, behaviour had normalised and the mares could be ridden again.

\section{Discussion}

The present study was initiated based on the experiences of ligation of the spermatic cord in abdominal cryptorchid horses by laparoscopic approach (Rijkenhuizen and Grinwis 1999, Voermans et al 2006). Spermatic cord ligation resulted in a $100 \%$ reduction of the testosterone production in these stallions. By using the same technique in mares and leaving the ovary in situ, no additional disruption of the abdominal wall for the exteriorisation of the ovary is necessary, reducing the risk of excessive post-operative swelling, infection or post-operative herniation. Additionally, ligation avoids sharp division of the mesovarium resulting in a reduced risk of bleeding and subsequent formation of adhesions which would be an advantage over the standard method of laparoscopic ovariectomy.
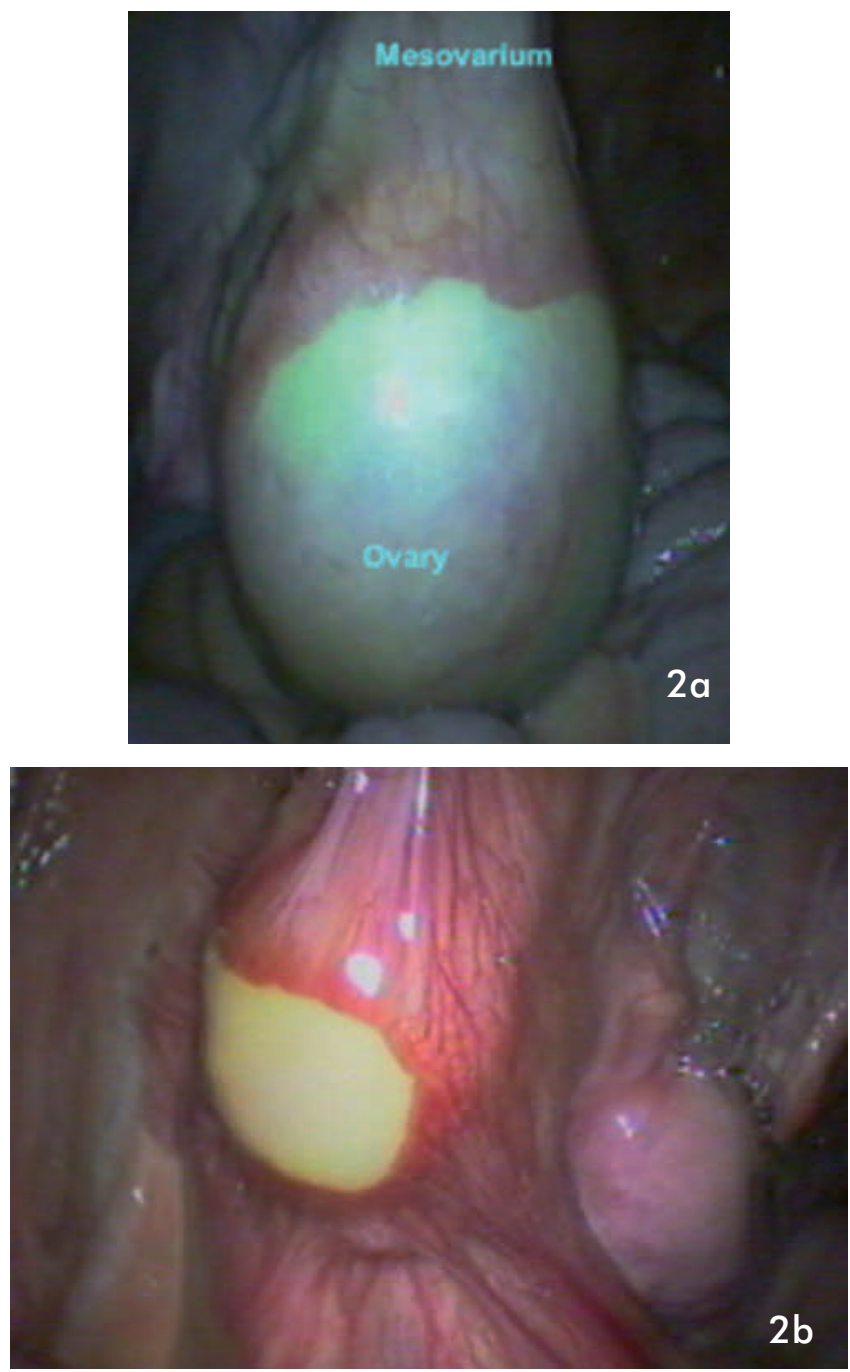

The anatomic situation of the ovary is comparable to the abdominal cryptorchid testicle, because it is a free pedicle attached to the mesovarium and the uterus; the abdominal testicle is a free pedicle attached to the mesorchium. We hypothesised that ligation of the pedicle would be sufficient to block the blood supply resulting in ischaemic necrosis of the ovary. However, we modified the procedure used for the abdominal testicle because the mesovarium is a broader structure than the mesorchium and ligation by just one ligature was not considered sufficient because the amount of tissue that had to be ligated was too voluminous to achieve enough pressure for closure of the arteries. It was therefore decided to focally perforate the mesovarium and ligate the cranial and caudal part separately. For security reasons, the cranial part was ligated twice to assure closure of the ovarian artery. Leaving a tissue bridge of less than $5 \mathrm{~mm}$ has been proven to be effective in ligation of the vessels (Rijkenhuizen et al. 2016).

From our study it became apparent that the procedure of a two-step ligation of the ovary, without removing the ovary, was successful in 15 out of the 18 ovaries $(83 \%)$, or 6 out of the 9 mares (67\%), making it not a fully trustworthy procedure using the current protocol. The ligated ovaries initially showed a small increase in size before most of the ovaries gradually became invisible laparoscopically. The initial increase in size of the ovaries is probably the result of congestion caused by

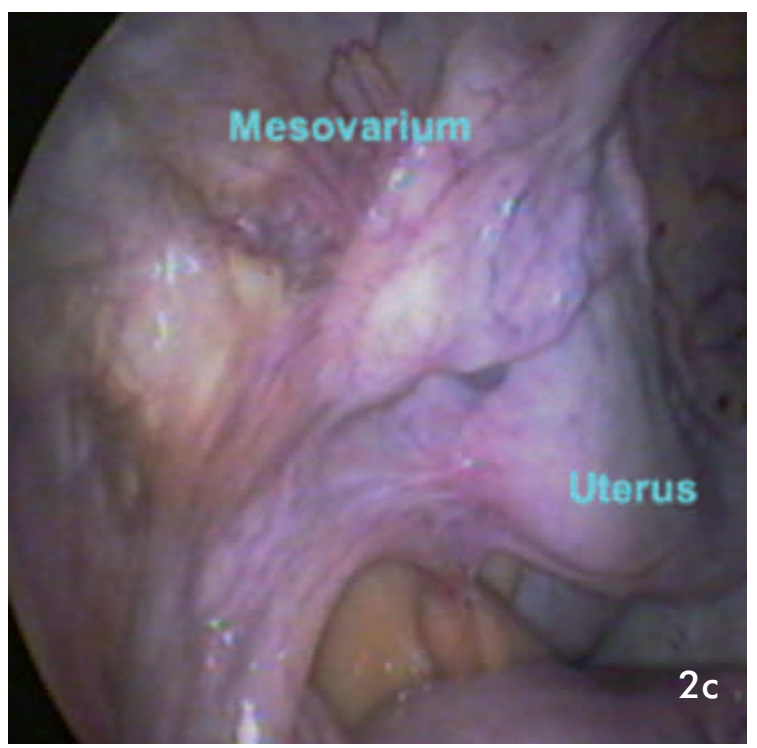

Fig. 2 Laparoscopic view of a non-congested ovary 14 (2a), 28 (2b) days and $5(2 c)$ months respectively after the initial surgery. a. The ovary has the aspect of a yellow smooth inert structure with a cap of granulation tissue growing over the ovary. b. The ovary has a yellow smooth serosal surface, the granulation tissue cap has increased in size, and covered $2 / 3$ of the ovary. c. The ovary can hardly be recognised and is embedded in the mesovarium. Laparoskopische Ansicht eines nicht gestauten Eierstocks 74 (2a), 28 (2b) Tage bzw. 5 (2c) Monate nach der ersten Operation. a. Der Eierstock hat eine gelbe, glatte und inerte Struktur mit einer Kappe aus Granulationsgewebe, die über den Eierstock wächst. b. Der Eierstock hat eine gelbe glatte serosale Oberfläche, die Granulationsgewebskappe hat sich vergrößert und bedeckt 2/3 des Eierstocks. c. Der Eierstock ist kaum zu erkennen und ist in das Mesovarium eingebettet. 
the ligation of the vessels in the mesovarium which was visualized by the presence of numerous congested blood vessels. This congestion resolved within 7-14 days.

The ligation of the mesovarium resulted in an increase in TP in the abdominal fluid 14 days after surgery, pointing to the presence of a peritoneal inflammation. The increase of TP after ligation has already been described to occur 24 and $72 \mathrm{~h}$ post-surgery in laparoscopic ovariectomy (Seabaugh et al. 2014) and also following laparotomy (Hanson et al. 1992) and castration (Schumacher et al. 1988). Instrumentation, ligation and manipulation of the organs resulted in greater TP

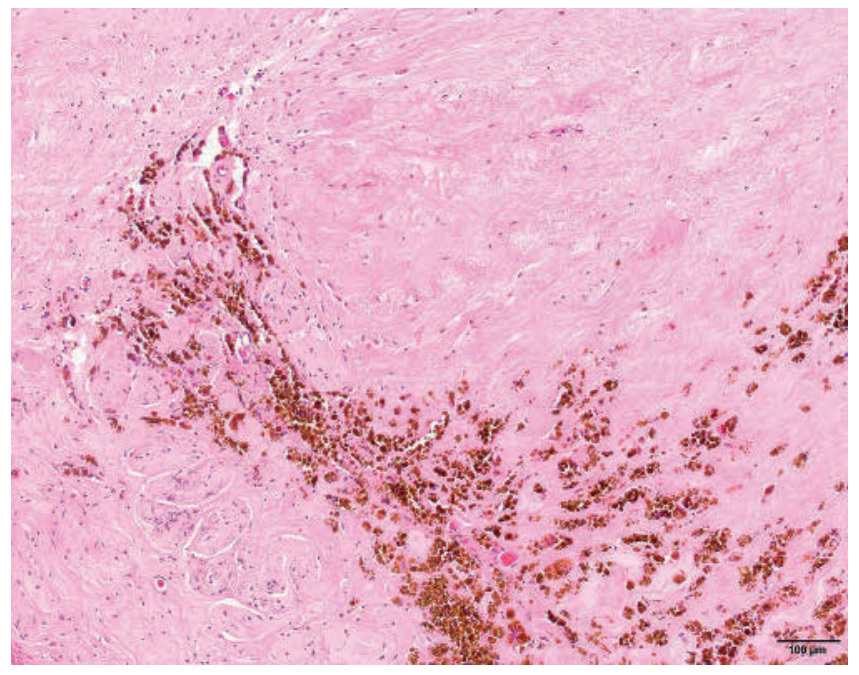

Fig. 3 Representative histology of a successfully ligated ovary. The ovarian region is characterized by cell-poor fibrous tissue with scattered groups of macrophages containing brown pigment (hemosiderin). Haematoxylin and eosin stain. | Repräsentative Histologie eines erfolgreich ligierten Ovars. Die Ovarialregion ist durch zellarmes fibröses Gewebe mit verstreuten Gruppen von Makrophagen gekennzeichnet, die braunes Pigment (Hämosiderin) enthalten. Hämatoxylinund Eosin-Färbung.

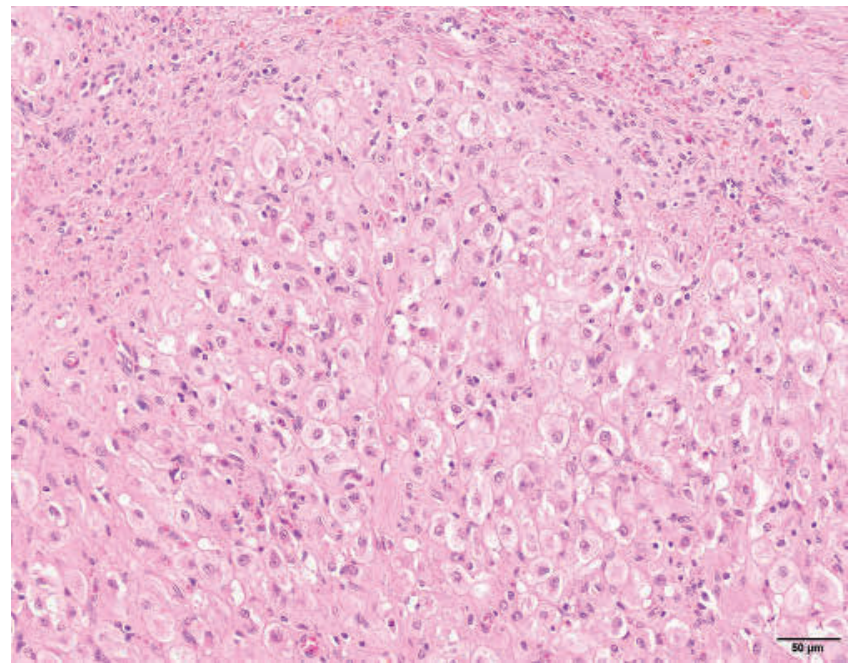

Fig. 4 Histology of one of the viable ovaries. An area with large, round to polygonal epithelioid cells consistent with luteal cells is visible. Haematoxylin and eosin stain. | Histologie eines der lebensfähigen Eierstöcke. Ein Bereich mit großen, runden bis polygonalen epitheloiden Zellen, die mit Lutealzellen übereinstimmen, ist sichtbar. Hämatoxylinund Eosin-Färbung. concentrations and WBCC in the abdominal fluid at 14 days post-operatively when compared to the analysis 28 days after the initial surgery in our study. At day 14 just an abdominal inspection had taken place without any intervention other than an abdominal incision. At 5 months, all values were within normal limits.

Leaving the ovary in situ caused no adverse clinical reactions. The formation of fibrous strands did not result in clinical signs. In only one mare a fibrous strand could be palpated transrectally and was noticed by the re-laparoscopy and necropsy. In the other pony the fibrous strand was only noticed by the

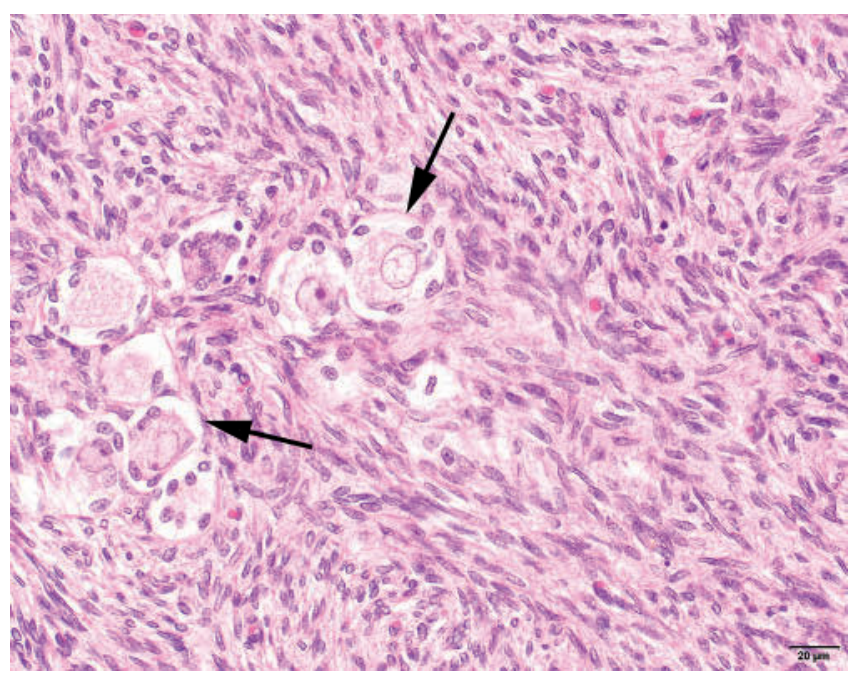

Fig. 5 Histology of the other viable ovary. Several primordial follicles (arrows) are situated within the cell-rich spindeloid tissue typical of the equine ovary. Haematoxylin and eosin stain. | Histologie des anderen lebensfähigen Ovars. Mehrere primordiale Follikel (Pfeile) befinden sich innerhalb des zellreichen spindeloiden Gewebes, das typisch für die Eierstöcke von Pferden ist. Hämatoxylin- und Eosin-Färbung.

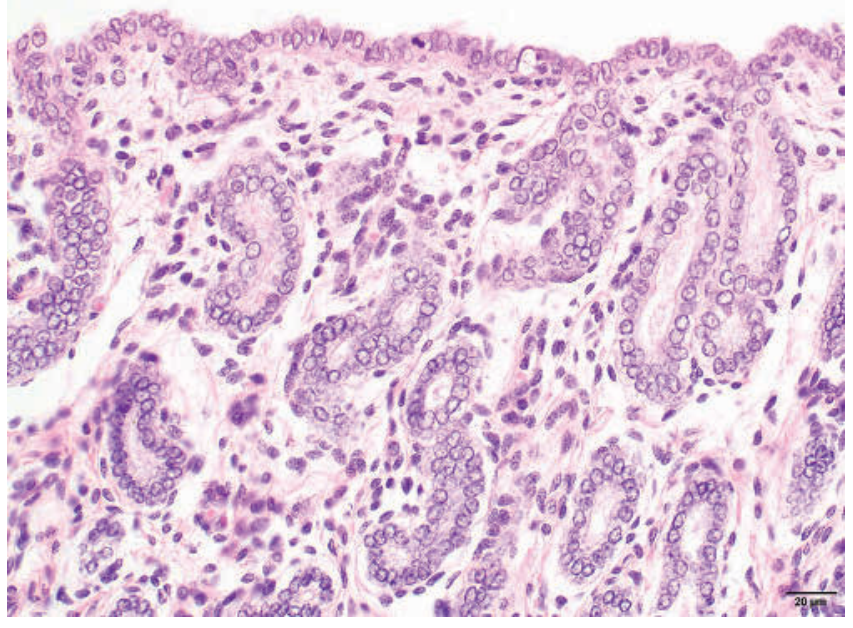

Fig. 6 Representative histology of the endometrium of a mare with a successfully ligated ovary showing an inactive aspect. The epithelial cells lining the surface and tubules are small and cuboidal. Endometrial glands are also small and contain only a little secretum. Haematoxylin and eosin stain. | Repräsentative Histologie des Endometriums einer Stute mit erfolgreich ligiertem Ovar, einen inaktiven Aspekt aufweisend. Die Epithelzellen, die die Oberfläche und die Tubuli auskleiden, sind klein und quaderförmig. Endometriumdrüsen sind ebenfalls klein und enthalten nur wenig Sekret. Hämatoxylin- und Eosin-Färbung. 
re-laparoscopy and necropsy. Adhesions are a common postoperative complication of abdominal surgery, although the adhesions do not necessarily cause clinical signs as is shown in our 2 ponies. Experiences with a high case load of laparoscopies in standing horses have shown that horses can have massive adhesions without any clinical signs (personal communication Rijkenhuizen).

Additionally, the occurrence of adhesions after a conventional or standard laparoscopic ovariectomy has not been studied as far as the authors are aware, and might occur as well without any clinical signs. The risk might even be higher because the ovaries are resected from the mesovarium leaving an incisional wound intra-abdominally.

In both studies on the effect of ligation of the abdominal testicles as well as the ovaries, the arteries and veins were ligated without being dissected or transected, thus reducing the risk of intra-abdominal bleeding and the formation of adhesions. The only difference between the procedure in stallions and mares was that the mesovarium had to be perforated to apply the ligature. The formation of fibrous strands probably occurred at the site where the mesovarium was perforated, and/ or might have originated from the granulation tissue overgrowing the ovary.

Failure of the presented castration technique occurred in 2 ovaries in 2 animals (in both the right-sided ovary) of the experimental group of 5 mares, and in 1 ovary (the left ovary) in the patient group of 4 mares. Failure of devitalisation of these three ovaries is thought to occur because of an ineffective

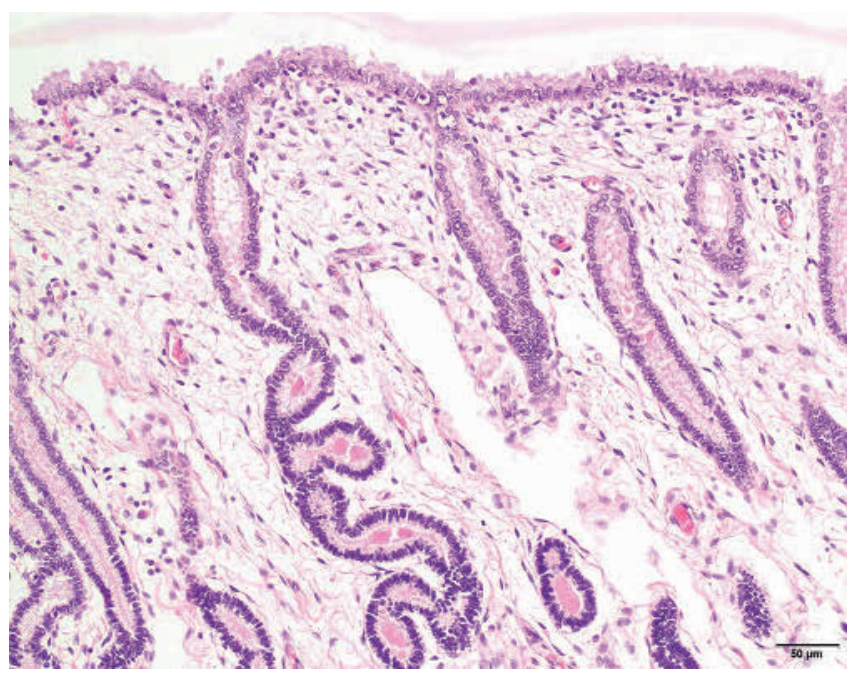

Fig. 7 Representative histology of the endometrium of a mare with a viable ovary revealing an inactive aspect of the mucosa. The epithelial cells lining the surface and tubules are markedly larger than in the inactive mucosa and cuboidal containing vacuolated cytoplasm suggestive of progesterone exposure. Endometrial glands are elongated and contain a marked amount of secretum. Haematoxylin and eosin stain. | Repräsentative Histologie des Endometriums einer Stute mit einem lebensfähigen Eierstock, einen inaktiven Aspekt der Schleimhaut zeigend. Die Epithelzellen, die die Oberfläche und die Tubuli auskleiden, sind deutlich größer als in der inaktiven Schleimhaut und enthalten quaderförmiges, vakuolisiertes Zytoplasma, das auf eine Progesteronexposition schließen lässt. Die Endometriumdrüsen sind länglich und enthalten eine deutliche Menge an Sekret. Hämatoxylin- und Eosin-Färbung. ligation of the mesovarium, as the result of slipping of the knot, insufficient tightening or revascularisation. Although experiences with laparoscopic surgery for ligation of the mesorchium of abdominal testicles has shown efficient ligation and $100 \%$ effective castration (Rijkenhuizen and Van Dijk 2002, Voermans et al. 2006), the more voluminous mesovarium pedicle, including adipose tissue, might have hampered sufficient tightening of the ligature resulting in inadequate compression of the artery and failure of the induction of ischemic necrosis of the ovarian tissue, thus responsible for a technical failure.

Evaluating the study, it seems more likely that the ligature was placed too close to the ovary, making it difficult to tighten the ligature enough to compress the artery. The expansive force within the compressed tissue near the ovary might be greater than the frictional resistance and the knot may loosen sufficiently to cause failure of the ligature. Interestingly, occlusion of the ovarian blood vessels as surgical sterilization technique in rat was successful in 19 out of the 20 ovaries (Taskin et al 1989). In the ovaries in which this technique was not successful, the ligature failed to close the ovarian vasculature. Whether the cyclic period might influence the size of the ovarian pedicle and thus the tension on the ligature was not considered by the authors at the moment of surgery, and no notes were made on the presence of follicles (size, number) or corpus luteum at the day of surgery. Improvement of the technique by avoiding disruption of the integrity of the mesovarium, for instance by using a double row of endostaples at a large enough distance of the ovary would be interesting to study. Another factor involved could be the material of the ligatures. Based on the earlier studies in stallions polyglactin ligatures were used in the mares, but previous research has indicated that polyglactin might be less suitable as a ligature compared to polydioxanone (Taylor and Grogono 2014).

The transrectal examination and ultrasonography performed by an experienced veterinarian at day 7 after surgery is not considered to cause loosening of the knot and if so, necrosis would already have been present. In humans, it is known that if ischaemia during more than $10 \mathrm{~h}$ has occurred, $80 \%$ of testicle becomes necrotic and after $24 \mathrm{~h}$ of ischaemia almost all testicles have lost viability (Dunne and O'Loughlin 2000.) In ovaries in cycling rodents, irreversible necrosis occurred following an ischaemic period of 36 hours by applying vascular clips (Taskin et al 1989).

The failure of the described technique on the ovary is different from the revascularisation in the descended testicle after ligation and transection of the spermatic cord. In stallions with a descended testicle, alternate blood supply to the descended testicle by vessels derived from the external pudendal artery is responsible for only 89-93\% successful castration (Voermans et al. 2006). In the presented procedure the whole pedicle of the ovary was ligated, we therefore think it is unlikely that alternate blood supply would have resulted in perfusion of the ovary. Revascularisation by a branch of the uterine artery would theoretically be possible; however, the time gap for revascularisation is small as mentioned before.

The formation of a cap of granulation tissue on all the ovaries, noticed at the relaparotomy at day 7 , is most likely a sign 
of tissue repair and is regarded as the consequence of the ligation. This formation of granulation tissue was also seen in some abdominal testicles, however never resulted in revascularisation (personal communication Rijkenhuizen). This could be explained by the difference in anatomy. The visceral tunic covers the visceral surface of the testicle, epididymis, spermatic vessels, and ductus deferens. The testicular tissue is encased in the tunica albuginea a capsule of fibrous tissue and smooth muscle (Sisson 1975), covered by peritoneum. Occlusion of the vessels will result in ischaemia and an increased intra-testicular pressure (ICP). The ICP, increases as venous outflow of the spermatic cord is occluded before cessation of arterial inflow (Kutikov et al. 2008). Due to the inelasticity of the testicular tunica albuginea, the chance of reperfusion is less due to the testicular oedema (consequence of the vessel ligation) and thus ischemia develops faster. The ovary is also surrounded by a tunica albuginea but it is likely that the ovarian tunica has a greater elasticity considering the fact that the size of the ovary varies substantially over the different seasons. The deep anoestrous ovary of a young mare may be less than $4 \mathrm{~cm}$ long, whereas at times during oestrus season the ovary with a number of large follicles can be greater than $10 \mathrm{~cm}$. Therefore the intra-ovarian pressure is probably lower than the intra-testicular pressure after occlusion of the vessels. That might explain why reperfusion might occur in the ovary and tightening of the ligature is therefore even more essential.

The reduced oestrogen and progesterone levels in pony number 5 might be explained by the small amount of vital ovarian tissue compared to the pony number 4 . Also at the relaparoscopy the size of the ovary of number 5 was reduced markedly compared to number 4 .

In conclusion, castration of mares by ligation, without removal of the ovaries, by laparoscopic intervention is possible and could potentially be an important step forward in the use of laparoscopy in equine medicine. The surgical technique for devitalisation of the ovaries in horses described in this report is safe and represents a method of castrating in the standing patient in a minimal invasive way, however, resulted in effective castration only in $67 \%$ of the mares. The failure is probably technique-based and it is anticipated that with increased experience and perhaps modification of the technique (e.g. the use of endostaples or the use of polydioxanone ligatures) could improve the success rate of this procedure. Surgery in the anoestrus period might also be an option as the ovaries are smaller and ligation might be easier.

Advantages include reduced tissue trauma, no risk of general anaesthesia, secure haemostasis, minimal invasive, rapid surgery, small incision ( 1 incision of $12 \mathrm{~mm}$ and 10 of $8 \mathrm{~mm}$ ), less risk of wound infection, reduced hospitalization time and a quicker return to normal work.

\section{Manufacturer's addresses}

${ }^{1}$ Domosedan ${ }^{\circledR}$, Pfizer Animal Health BV Capelle aan de IJssel, the Netherlands.

2 Temgesic ${ }^{\circledR}$, Schering-Plough, Maarssen, the Netherlands.

${ }^{3}$ Alfacain $2 \%$ and Adrenaline, Alfasan, Woerden, the Netherlands
${ }^{4}$ Storz $^{\circledR} \mathrm{GmbH} \&$ Co. Tuttlingen, Germany.

${ }^{5}$ Dr.Fritz ${ }^{\circledR}$ Endoskopie- \& Dokumentations-Systeme, Tuttlingen, Germany.

${ }^{6}$ Vicry ${ }^{\circledR}$, Ethicon, Johnson \& Johson, Amersfoort, the Netherlands.

${ }^{7}$ Monocryl ${ }^{\circledR}$, Ethicon, Johnson \& Johson, Amersfoort, the Netherlands.

\section{References}

Dunne P. J., O'Loughlin B. S. (2000) Testicular torsion: time is the enemy. Aust. N. Z. J. Surg. 70, 441-442

Dijk van P., Lankveld D. P. K., Rijkenhuizen A. B. M., Jonker F. H. (2002) Hormonal, metabolic and physiological effects of laparoscopic surgery under a sedative analgesic combination of detomidine and buprenorphine in standing equines. Vet. Anaesth. Analg. 30 , 267-268

Gutjahr S., Paccamontr D. L., Pycock J. F., Taverne M. A. M., Dieleman S. J., Van der Weijden G. C. (2000) Effect of dose and day of treatment on uterine response to oxytocin in mares. Theriogenology 54, 447-456

Hanson R. R., Nixon A. J., Gronwall R., Meyer D., Pendergast J. (1992) Evaluation of peritoneal fluid following intestinal resection and anastomosis in horses. Am. J. Vet. Res. 53, $216-221$

Kutikov A., Casale P., White M. A., Meyer W. A., Chang A., Gosalbez R., Canning D. A. (2008) Testicular Compartment Syndrome: A New Approach to Conceptualizing and Managing Testicular Torsion. Urology 72, 786-789; DOI 10.1016/i.urology.2008.03.031

Nickels F. A. (1988) Complications of castration and ovariectomy. Vet. Cli.n North Am. Equine Pract. 4, 515-523

Ono M., Akuzawa H., Nambo Y., Hirano Y., Kimura J., Takemoto S., Nakamura S., Yokota H., Himeno R., Higuchi T., Ohtaki T., Tsumagari S. (2015) Analysis of the equine ovarian structure during the first twelve months of life by three-dimensional internal structure microscopy. J. Vet. Med. Sci. 77, 1599-1603; DOI 10.1292/jvms.14-0539

Palmer S. E. (1993) Standing laparoscopic laser technique for ovarectomy in five mares. J. Am. Vet. Med. Assoc. 203, 279-283

Rijkenhuizen A. B. M. (2002) Diagnostic and therapeutic laparoscopy in the horse: experiences in 236 cases. Pferdeheilkunde 18, 12-20; DOI 10.21836/PEM20020102

Rijkenhuizen A. B. M., Grinwis G. C. M. (1999) Castration of the stallion: preferably in the standing horse by laparoscopic techniques? Pferdeheilkunde 16, 425-429; DOI 10.21836/PEM19990504

Rijkenhuizen A. B. M., Sommeraver S., Fasching M., Velde K., Peham C. (2013) How securely is the testicular artery occluded in the spermatic cord by using a ligature? Equine Vet. J. 45, 649-652

Röcken M., Mosel G., Seyrek-Intas K., Seyrek-Intas D., Litzke F., Verver J., Rijkenhuizen A. B. M. (2011) Unilateral and bilateral laparoscopic ovariectomy in 157 mares: a retrospective multicenter study. Vet Surg. 40, 1009-1014. DOI 10.1111/i.1532950X.2011.00884.x.

Sazonov V. S., Endolov V. V. (1981) Delayed type autoimmune reaction after ligation of the vascular bundle of the test. Bull. Experim. Biol. Med. 92, 1536-1538

Schoon H-A., Schoon D., Klug E. (1992) Endometrial biopsies as an ancillary aid in diagnosis and prognosis of subfertility in the mare. Pferdeheilkunde 6, 355-362; DOI 10.21836/PEM19920603

Schumacher J., Spano J. S., McGuire J., Scrutchfield W. L., Feldman R. G. (1988) Effects of castration on peritoneal fluid in the horse. J. Vet. Int. Med. 2, 22-25

Seabaugh K. A., Goodrich L. R., Bohn A. A., Morley P. S., Hendrickson D. A. (2014) A comparison of peritoneal fluid values in mares following bilateral laparoscopic ovariectomy using a vessel sealing and dividing device versus placement of two ligating loops. Vet. J. 202, 297-302; DOI 10.1016/i.tvil.2014.08.025.

Silva L. A. F., Pales A. P., Fioravanti M. C. S., Pádua J. T., Silva O. C., Santos K. J. G. (2006) Anel de látex aplicado no pedículo ovariano de bezerras Nelore. Acta Sci. Anim. Sci. 28, 97-103 
Sisson S. (1975) Equine urogenital system. R. Getty (Ed.), Sisson and Grossman's Anatomy of the Domestic Animals (5th edition), WB Saunders, Philadelphia

Taskin O., Birincioglu M., Aydin A., Buhur A., Burak F., Yilmaz l., Wheeler J. M. (1998) The effects of twisted ischaemic adnexa managed by detorsion on ovarian viability and histology: an ischaemia-reperfusion rodent model. Hum. Reprod. 13, 2823-2827; DOI 10.1093/humrep/13.10.2823
Taylor H., Grogono A. W. (2014) The constrictor knot is the best ligature. Ann Royal Coll. Surg. Engl. 96, 101-105; DOI 10.1308/00 3588414 X13814021677638

Voermans M., Rijkenhuizen A. B. M., van der Velden R. (2006) The complex blood supply to the equine testis as a cause of failure in laparoscopic castration. Equine Vet. J. 38, 35-39

Erweiterte Zusammenfassung

\section{Wirksamkeit der laparoskopischen Ligatur des Mesovariums der Stute im Stehen ohne Entfernung des Eierstocks}

Die Indikationen für die Entfernung von Ovarien umfassen Verhaltensveränderungen, Prävention des Östrus bei gerittenen Stuten und ovarielle Erkrankungen wie Zysten, Hämatome, Abszesse und Tumor. Bei einer Ovariektomie mithilfe der konventionellen Chirurgie scheinen im Vergleich mit anderen elektiven Eingriffen wie die Kastration des Hengstes öfter perioperative Komplikationen aufzutreten. Diese Komplikationsrate konnte durch die laparoskopische Entfernung der Ovarien reduziert werden. Doch muss auch bei diesem Verfahren um das Ovar entfernen zu können der Instrumenten-Port immer noch vergrößert werden und dies bedingt ein erhöhtes Risiko einer Wundinfektion. Des Weiteren besteht das Risiko der Bildung von Adhäsionen im Bereich des ovariellen Stumpfes. Um die Komplikationsrate weiter zu reduzieren wurde eine Technik entwickelt ähnlich der der laparoskopischen Kastration bei Hengsten. Bei dieser wird das Ovar nicht entfernt, sondern es erfolgt nur eine Ligatur des Mesovariums und des Ligamentum ovarii proprium. In der vorliegenden Untersuchung erfolgte bei fünf Stuten in einem Alter zwischen 3 und 16 Jahren mit klinisch unauffälligen Ovarien eine laparoskopisch durchgeführte Ligatur der oben genannten Strukturen. Der Eingriff erfolgte unter Stehend-Sedation mit Detomidin (0,1 mg/100 kg BWT i.v.) und Buprenorphin (0,06 mg/100 kg BWT i.v.). Die Sedierung wurde aufrechterhalten durch eine kontinuierliche Infusion mit Detomidin. Nach Vorbereitung des Operationsfeldes und lokaler Infiltrationsanästhesie (subkutan, intramuskulär, subperitoneal) erfolgte eine bilateral durchgeführte Laparoskopie mit Ligatur des Mesovariums einschließlich der ovariellen Arterie und Vene. Der Port für das Laparoskop wurde kurz dorsal des M. obliquus internus abdominis und $2 \mathrm{~cm}$ kaudal der letzten Rippe gelegt. Das Abdomen wurde mit Kohlendioxid insuffliert bis zu einem maximalen intra-abdominalen Druck von $6 \mathrm{mmHg}$. Der Instrumenten-Port wurde $4 \mathrm{~cm}$ kaudal und 8-10 cm distal zu dem laparoskopischen Port gesetzt. Ein dritter Port wurde zwischen den beiden gelegt. Zunächst wurde das Mesovarium mit Lidocain anästhesiert und daraufhin mit einer unipolaren Schere perforiert und zwar genau kaudal zum Ovar und dorsal zum Ligamentum ovarii proprium. Durch dieses Loch wurde ein Faden (Polygactin USP2) von lateral nach medial gelegt, dieser mit einer Klemme gegriffen, nach extracorporal gezogen und dort verknotet. Eine zweite Ligatur umfasste den kaudalen Teil des Mesovariums, den Ovidukt und Mesosalpinx. Da die A. ovarica weiter kranial liegt wurde eine dritte Ligatur $5 \mathrm{~mm}$ kranial der ersten gelegt. Dieselbe Prozedur erfolgte über die linke Flanke. Blutprobenentnahmen für die Bestimmung der Konzentrationen von Östrogen und Progesteron erfolgten präoperativ sowie 1, 7, 14, 28 Tage und fünf Monate nach dem Eingriff. Bei den Stuten erfolgte eine bilaterale Re-Laparoskopie 14 sowie 28 Tage und fünf Monate nach dem initialen Eingriff. Nach fünf Monaten wurden die Pferde euthanasiert und eine Sektion durchgeführt. Die Ovarien und der Uterus wurden makroskopisch und histologisch untersucht. Des Weiteren wurde dieser laparoskopischen Eingriff bei vier Patienten durchgeführt. Bei den Eingriffen der Stuten traten keine Komplikationen auf. Die Visualisierung der Ovarien und des Mesovariums waren gut. Die durchschnittliche Daver des Eingriffes betrug 42 Minuten. Die Perforation des Mesovariums verursachte keine Schmerzreaktion der Stuten. Postoperative Komplikationen traten nicht auf. Bei sieben von neun Stuten waren die durchschnittlichen Konzentrationen von Östrogen und Progesteron nach der laparoskopischen Kastration niedrig. Der laparoskopische Eingriff mit einer Ligatur in zwei Schritten ohne Entfernung der Ovarien war bei 15 von 18 Ovarien (83\%) erfolgreich. Die laparoskopische Kastration der Stute durch Ligatur ohne Entfernung der Ovarien ist möglich, sicher und stellt ein Verfahren der minimalinvasiven Kastration beim stehenden Patienten dar. Allerdings war die Kastration nur bei 6 von 9 Stuten effektiv. Um die Erfolgsrate dieses Eingriffes zu verbessern, muss eine Modifikation des Verfahrens erfolgen.

Schlüsselwörter: Stute, Kastration, Ovariektomie, Stehend-Operation, Wirksamkeit 